\title{
ANALYSIS OF THE LEGAL METHODS OF AGRICULTURAL LAND PROTECTION IN CENTRAL EUROPE ON THE EXAMPLE OF POLAND AND BULGARIA
}

(1)Elżbieta Pawlikowska, M. Sc. AGH University of Science and Technology e-mail:ebpawlikowska@gmail.com

\section{(3)Agnieszka Bieda, Ph. D.} AGH University of Science and Technology e-mail:agnieszka.bieda@agh.edu.pl

(5)Ana Stoeva, Ph. D. Prof. Eng.

University of Architecture, Civil Engineering and Geodesy, Sofia

e-mail:anastoevabg@yahoo.com
(2)Paulina Popek, M. Sc.

AGH University of Science and Technology

e-mail:popekpaulinaa@gmail.com

(4)Milena Moteva, Ph. D. Assoc. Prof. Eng. University of Architecture, Civil Engineering and Geodesy, Sofia

e-mail: moteva_fgs@uacg.bg

\begin{abstract}
${ }^{1}$
For the management of agricultural real properties to be effective, it is required that information about the natural conditions and the existing infrastructure supporting agricultural production, as well as knowledge of the regional traditions, be provided. The management itself should also be based on sound legislation. Due to the fact that agricultural real properties are subject to special legal protection, this article aimed to analyze and assess the methods of managing agricultural real property in the new EU member states on the example of Poland and Bulgaria. This objective was implemented by presenting the structure of agricultural land and the state of agriculture, describing the agrarian reforms, determining the current role of spatial planning and the binding regulations in the management of agricultural land resources, as well as a description of the current surveying procedures. Basing on the outlined comparative characteristics, SWOT/TOWS analysis was performed.

The result of this comparative study is the highlighting of the problems and recommendations for the management of agricultural properties in Poland and Bulgaria.
\end{abstract}

Key words: agricultural land, legal methods of protection, land management.

JEL Classification: $Q 15$.

Citation: Pawlikowska E., Popek P., Bieda A., Moteva M., Stoeva A., 2017, Analysis of the Legal Methods of Agricultural Land Protection in Central Europe on the Example of Poland and Bulgaria, Real Estate Management and Valuation, vol. 25, no. 2, pp. 58-71.

DOI: 10.1515/remav-2017-0013

\footnotetext{
1 This study has received the financial support from statutory research No. 11.11.150.006 of AGH University of Science and Technology, allocated for the year 2017.
} 


\section{Introduction - agricultural land and the state of agriculture}

Profitable farming is not just a matter of proper soil conditions, climate and water management (PRUS, SALATA, 2014), but also of the rational management of land resources (RACKA et al., 2015), including their protection (SKINNER et al., 2001), (BRABEC, SMITH, 2002). The effective management of agricultural land should be based on solid legal foundations (BIEDA et al., 2014). It also requires information on the natural conditions and the existing infrastructure to support agricultural production.

Taking the above assumptions into account, this paper is aimed at presenting and evaluating the methods of legal protection of agricultural land resources in new European Union member states, such as Poland and Bulgaria. It is implemented through the rough description of activities aimed at the protection of agricultural land which are conducted in these countries, and the SWOT/TOWS analysis of these activities.

Pursuant to the provisions of the Polish Civil Code (ACT, 1964), the agricultural real properties (agricultural land) include those which are, or may be, used for agricultural production in the scope of plant and animal production, including horticultural, orchard and fish production. Further regulations in the Polish legal system, that is, the regulation on land records (ROZPORZĄDZENIE, 2001), specify that the agricultural land is divided into farmland and wasteland. Farmland includes: arable land, orchards, meadows and permanent pastures, developed agricultural land, land under ponds and ditches, as well as farmland covered with trees and shrubs.

The definition was extended in the Act on the Protection of Agricultural and Forest Land (UsTAWA, 1995). Pursuant to its provisions, the agricultural land, other than that specified in the register of land and buildings (ROZPORZĄDZENIE, 2001), includes the land:

- under fish ponds and other water bodies which serve exclusively for agricultural needs,

- under residential buildings belonging to farms, and other buildings and facilities intended exclusively for agricultural production and the food processing industry,

- under the buildings and facilities intended for agricultural production considered to be a special branch, pursuant to the provisions on the personal income tax and corporate income tax,

- rural parks, under field woodlands and bushes, including under wind protection belts and antierosion devices,

- allotment gardens and botanical gardens,

- under the devices for: water drainage, flood and fire protection, water supply for agricultural purposes, sewerage and disposal of sewage and waste for the purposes of agriculture and rural residents,

- reclaimed for agricultural purposes,

- peatbogs and ponds,

- under access roads to agricultural land.

The legal definition of agricultural land in the Bulgarian legislation (LAW, 1991) defines agricultural land as that which is used for agricultural production and is not included in one of the other two main areas - urban and forest, also is not under buildings, industrial or other business enterprises, recreation or health institutions, religious communities or other public organizations, or represent yards or warehouses of such buildings, occupied by open mines and quarries, by energy, irrigation, transportation or other facilities for common use, or represent adjacent parts to such facilities. In addition, agricultural production, as a term, is defined in the Act on the Protection of Agricultural Land (LAW, 1996) and includes the production of crops and grazing, which are to be performed with no harm to the fertility or condition of the soil.

According to the authors, it can be assumed that both, in Bulgaria and in Poland, the natural conditions for agricultural development are very good. Relief, climate, soil condition and water resources have a significant influence on vast agricultural land resources (Figure 1).

The relief in Bulgaria is diversified, whereas Poland is considered to be a lowland country. In Poland, areas up to $800 \mathrm{~m}$ above sea level cover over $95 \%$ of the territory, while in Bulgaria this is about $75 \%$. As far as soil is concerned, more than half of Bulgarian soils are deep and fertile types, while in Poland, good quality soil accounts for only $23 \%$. On the other hand, as has already been mentioned, Poland has more favorable topographic conditions for the development of agriculture than mountainous Bulgaria. 


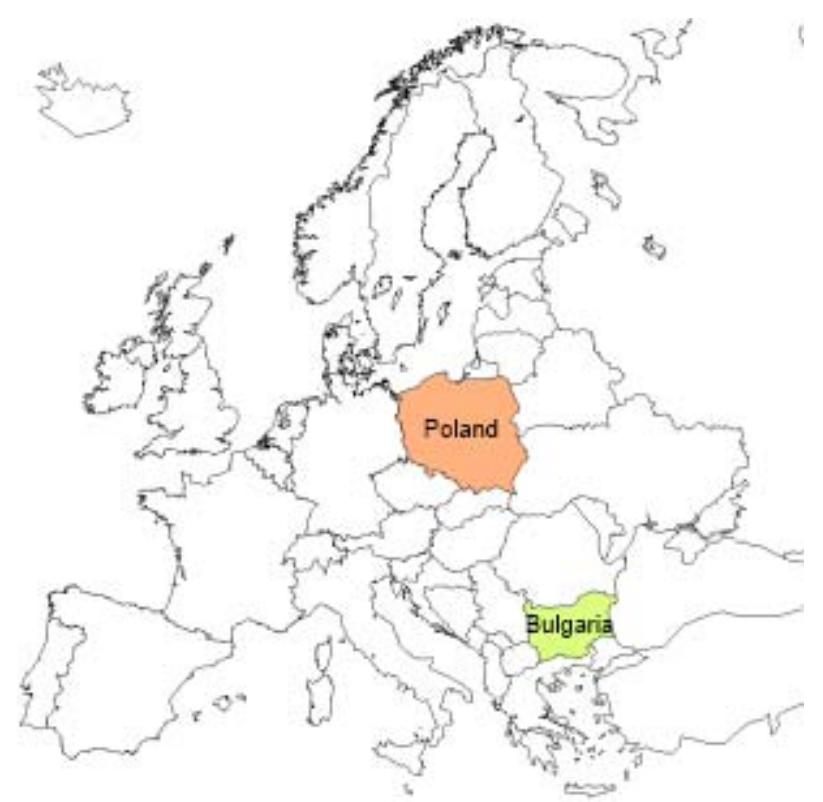

relief: mostly flat plains; mountains along the southern border

climate: temperate; harsh winters; mild summers with frequent storms soil: $23 \%$ of good quality soil water resources: low

\section{reficive}

relief: diverse with plains in north and lowlands in southeast

climate: temperate; cold, damp winters; hot, dry summers

soil: more than $50 \%$ of fertile soil

surface water resources: evenly spread over the territory of the country

Fig. 1. Natural factors affecting the size of agricultural land resources in Poland and Bulgaria.

Source: Own study based on (THE WORLD FACTBOOK).

Bulgarian freshwater resources originate from the mountains. Agriculture and agricultural practices are strongly influenced by the limited atmospheric resources which are unevenly distributed throughout the country (MOTEVA et al., 2014). This means that in the period of the potential growing season, irrigation is recommended to obtain high and stable crop yields. The territory of Poland is characterized by relatively low water resources resulting from the amount of rainfalls and their seasonal diversity.

The location of Poland and Bulgaria at different latitudes results in their slightly different climatic zones. For this reason, the average monthly temperatures in Bulgaria are higher than those in Poland, where low winter temperatures used to damage plants and seedlings. In Poland the annual precipitation total is higher than that in Bulgaria (especially in the summer months), which carries the threat of flooding. On the other hand, some regions in Bulgaria suffer from a total lack of rainfalls (KAZANDJIEV et al., 2009). However, despite the above, both countries enjoy climatic conditions considered to be quite good for agricultural purposes.

According to the latest data of the Head Office of Geodesy and Cartography, the proportion of the agricultural land in Poland is currently 59.9\%. In Bulgaria, the ratio of farmland relative to the total area is $58.3 \%$ - these are data collected by the Ministry of Agriculture and Food of Bulgaria (2011). The land use in Poland and Bulgaria has been presented in Table 1.

Table 1

Land use in Poland and Bulgaria

\begin{tabular}{cccc}
\hline POLAND & \multicolumn{2}{c}{ BULGARIA } \\
\hline Direction of land use & In $\%$ & Direction of land use & In \% \\
\hline agricultural land & 59.9 & agricultural land & 58.3 \\
\hline $\begin{array}{c}\text { forest land as well as woody and } \\
\text { bushy land }\end{array}$ & 30.9 & forest area & 34.7 \\
\hline land under waters & 2.1 & surface of water & 1.8 \\
\hline minerals & 0.1 & - & - \\
\hline transport areas & 2.9 & transport areas & 0.6 \\
\hline residential areas & 2.2 & urban area & 4.3 \\
\hline wasteland & 1.5 & damaged territory & 0.2 \\
\hline
\end{tabular}

Source: (GUS, 2014), (MAF, 2011). 
In 2013, the share of agriculture in the GDP accounted for only $4.0 \%$ in Poland and $6.7 \%$ in Bulgaria. The remaining percentage is represented by industry and services (THE WORLD FACTBOOK).

\section{Agrarian reforms}

The introduction of legislative changes in the form of agrarian reforms had positive and negative consequences in these countries. Both in Poland and in Bulgaria, land reform has brought change to the old state and cooperative structures, as well as resulting in favorable conditions for agricultural law. Small-sized individual farms have been developed in both countries.

Thus, in Poland, in order to strengthen the protection and the development of family farms, and to ensure the proper management of agricultural land, as well as to provide food security for the citizens, and to promote sustainable agriculture, run in accordance with the requirements of environmental protection, and supporting the development of the rural areas, the act on shaping the agricultural system was established (USTAWA, 2003b). It defines the rules for shaping the agricultural system of the country through:

- improving the area structure of the farms,

- preventing the excessive concentration of agricultural property,

- ensuring that agricultural activity on farms is carried out by persons with appropriate qualifications.

Pursuant to (USTAWA, 2003b), only an individual farmer may be the purchaser of agricultural real estate. In the case of the sale of agricultural property which had been leased, the lessee shall have the right of pre-emption. There are, of course, exceptions to these rules. They do not, however, diminish the legal protection of the agricultural land.

One of the surveying and legal processes which support the management of the farm size in Poland includes the consolidation and exchange of land, which is currently applied to agricultural and forest land (USTAWA, 1982a). This procedure aims to improve the functionality of agricultural land, or to introduce changes in the system of ownership, to provide for new water management facilities, roads or better use of the existing relief.

The Agrarian reforms have brought about the collection of state funds. In Poland, agricultural land has been accumulated by the Agricultural Property Agency of the Treasury (now the Agricultural Property Agency).

The latest regulation of the Polish law concerning agricultural property is the Act on Suspension of the Sale of the Property of the Treasury Agricultural Property Stock. Some laws were amended (UsTAWA, 2016), which stopped the sale of the real estate belonging to the Treasury Agricultural Property Stock.

Land Funds and Land Banks are instruments which are primarily used to solve the problem of land fragmentation in the countries of Central Europe, including Poland and Bulgaria. Land Banks use significant amounts of land, more or less directly controlled by the national government or local authorities. In Bulgaria, the idea of a Land Bank underlies in the Strategy for Land Consolidation 2007-2013, which, unfortunately, was not implemented. Currently, occasional land funds are managed by Joint-Stock Companies with Special Investment Objective (LAW, 2003). State lands and those of municipalities also serve the Agricultural Land Policy of the State. It should be noted, however, that a significant part of the resources of Bulgarian land is leased out. Research or educational institutions use state land as well. A contemporary solution for land funds are the Land-Use Arrays based on land consolidation of the leased land in each village. The formation of the Land-Use Arrays is regulated by the Law on the Ownership and Use of Agricultural Land (LAW, 1991). On the other hand, in Poland, the Agricultural Property Agency is preoccupied with restructuring and exercising the right of ownership in relation to state agricultural property. Besides carrying out sales of agricultural land or letting it for lease, the Agency can also give away land, free of any charge, for purposes related to the development of infrastructure, to the State Forests for afforestation, to the Polish Academy of Sciences, universities or research and development centers.

The structure of agricultural land in Bulgaria is more fragmented than in Poland. This is caused by the lack of (DAVIDOVA et al., 1997; MOTEVA et al., 2014):

- effective state policy during the agrarian reform, which should strengthen the process of land consolidation, 
- a legal mechanism that could prevent the further process of real estate subdivision through inheritance and sales,

- proper management of land and water resources.

Bulgarian agricultural production is still characterized by its dualistic structure. There are a relatively small number of large farms covering a considerable part of agricultural land, and a large group of small farms covering a small part. Over the years, there have been many informal agreements regarding the transfer of ownership rights, such as leasing or renting. Some of them have survived until nowadays. The mosaic structure of land in Bulgaria has contributed to neglecting the irrigation systems and, therefore, to losses in GDP.

Currently, there are no legal mechanisms for preventing further fragmentation of agricultural land ownership beyond 0.3 ha for field crops, 0.2 ha for meadows and 0.1 ha for perennial plantations in Bulgaria (LAW, 1949). Appropriate legislation on the consolidation of land property and state control on the land market will contribute to efficient agricultural land use, i.e. applying proper mechanization, efficient irrigation, soil conservation and landscape protection.

The unresolved problems of agriculture in Poland are similar to those above. The main problem is the huge fragmentation of agricultural land, although on a smaller scale than in Bulgaria. Moreover, the inefficient agrarian reform and an absurd planning system following World War II led to the economic crisis in Poland. The agricultural market in Poland was underdeveloped and formed slowly. Additionally, during a mass re-privatization of land after 1989, there were numerous claims of the heirs of the former land owners whose property was appropriated without any compensation. Since Poland chose sales as the main manner of privatization, the land was purchased by people who were not engaged in it, but had the purchasing power at that time.

Table 2 demonstrates that the area structure of farms in Poland is diverse. More than half of the Polish farms have a surface area which does not exceed 5 ha. However, agricultural land in Bulgaria tends to be even more fragmented, as the percentage of farms of less than 1 ha in size reaches $70.6 \%$. The number of farms larger than 50 hectares is similar in both countries and accounts for about $2 \%$.

Table 2

The number and size of farms in Poland and Bulgaria

\begin{tabular}{cccccc}
\hline \multicolumn{7}{c}{ POLAND } \\
\hline Total & $<5$ ha & $5-20$ ha & $20-50$ ha & $50-100$ ha & $>100$ ha \\
\hline $1,394,632$ & 732,840 & 526,725 & 103,246 & 20,743 & 11,077 \\
\hline $100 \%$ & $52.5 \%$ & $37.8 \%$ & $7.4 \%$ & $1.5 \%$ & $0.8 \%$ \\
\hline \multicolumn{7}{c}{ BULGARIA } \\
\hline Total & $<1$ ha & $1-2$ ha & $2-10$ ha & $10-50$ ha & $>50$ ha \\
\hline 370,222 & 261,163 & 46,944 & 41,124 & 12,828 & 8,163 \\
\hline $100 \%$ & $70.6 \%$ & $12.7 \%$ & $11.1 \%$ & $3.5 \%$ & $2.2 \%$ \\
\hline
\end{tabular}

Source: (GUS, 2014), (MAF, 2011).

\section{Public records relating to real estate}

The record of rights and the collection of technical data relating to the real estate are tasks which are carried out in the same manner in Poland and in Bulgaria. In both of these countries, there are two separate, but closely related registers. Agricultural land is recorded in the same way as any other.

In Bulgaria there are two IT systems: the Cadastre and the Real Estate Register. The Cadastre is the base for the creation of the Real Estate Register, and this is one of its main functions. It is not possible to make an entry in the Real Estate Register if there is no data from the Cadastre, and if there is no real estate identifier.

Currently, the legal framework for the two registers in Bulgaria is contained in a single act - the Cadastre and Property Register Act (CPRA, 2000). According to this act, these records are used to protect the rights to property, and they should meet the needs and interests of all the cadastral subjects: the rights of the holders and the rights of the users. 
The Real Estate Register collects information about all the registered documents which state rights to real properties, and about any mortgages. The Real Estate Register is kept by the Registry Agency of the Ministry of Justice.

The cadastral data in Bulgaria is presented in two forms: as cadastral maps and as cadastral registers. Ultimately, they should be created in a digital form, but this is a lengthy process which began in 2001 and has not yet been completed. The new cadastral maps cover only $18.2 \%$ of the territory of the country. For the most part of the agricultural and forest land, cadastral and other types of information are being kept in the so-called Maps of the Restored Property Rights, which are cadastral-like maps with registers. They are kept by the Ministry of Agriculture and Food. The Cadastre in Bulgaria is kept by the Agency of Geodesy, Cartography and Cadastre of the Ministry of Regional Development and Public Works. The responsibilities of these two authorities include the preparation, maintenance, and control of the maps and cadastral registers, as well as the provision of data. The cadastre compiles data on the location, boundaries and surface areas of real properties, as well as the rights to them, only in regions with approved data.

In Poland, the two main public real estate records are the Register of Land and Buildings (USTAWA, 1989), (RZOPORZĄDZENIE, 2001) and Land and Mortgage Registers (UsTAWA, 1982b).

The rights relating to real estate are contained in Land and Mortgage Registers. However, real property designation in these Registers is based on the technical data derived from the Register of Land and Buildings. The main function of the Land and Mortgage Registers is to determine the legal status of a real property, which is needed to protect the real estate market turnover and loans secured by mortgages. This Register contains full legal information, but the scope of descriptive data about a real property is reduced to the absolute minimum required.

On the other hand, the cadastre provides full information on the factual status on land, buildings and premises, but the information on the legal status of a real property is limited. In view of the purpose of the cadastre, the data contained therein are informative (FELCENLOBEN, 2010). The cadastre covers the entire territory of Poland. It is created and run by a computer system, which is based on databases. The cadastre is managed by a staroste who stores, processes and prepares the information on the cadastral status of the available objects.

\section{Spatial planning}

Spatial planning in Bulgaria is a dual process - roughly speaking, there are two segments which can be distinguished in the system: "development plan" governed by the Regional Development Act (RDA, 2008) and the segment "spatial planning" based on the Spatial Planning Act (SPA, 2001).

The first Act (RDA, 2008) regulates the issues of planning, management, providing resources, monitoring, control and evaluation of strategies, plans and programs for the implementation of the state policy for regional development, and the issues of land use at national, regional, county and municipal levels. The second Act (SPA, 2001) regulates social relations related to spatial planning, investment planning, development and land use - spatial planning at the most detailed level.

In fact, the plans developed under these two segments should be implemented in parallel, and should complement each other; in practice, however, they function autonomously. Nevertheless, it is worth noting that the entire area of Bulgaria is covered by the provisions of the development plan at the local level - the one which is the most detailed.

Bulgarian regulations on spatial planning provide for the creation of agricultural development plans, although, at the moment, this provision is not binding. The function of such a plan is to improve the quality and productivity of agricultural land, but the legislation lacks a strict definition of this instrument.

The basic legal act on spatial planning in Poland is the Spatial Planning and Development Act (UsTAWA, 2003a), pursuant to which the process of spatial planning aims to identify the areas for the implementation of selected objectives, and to determine their mode of use, adopting the principle of sustainable development as the basis for action. The Act regulates the formation of spatial policy at various administrative levels, i.e. at municipal, provincial and national levels.

With regard to agricultural land, the Act requires that spatial planning should take into account the requirements of environmental protection, including the protection of agricultural and forest land. The plans drawn up at the local (municipal) level are supposed to regulate these issues by identifying, for example, the principles of environmental protection and the protection of nature and the cultural 
landscape, as well as by specifying restrictions on land use, including the prohibition of land development and identifying the boundaries of areas requiring restructuring and reclamation.

In addition, the Environmental Protection Law (USTAWA, 2001) states that any type of planning document is to be preceded by an ecophysiographic report. This strategic document is necessary to determine the suitability of land for utility functions, including the agricultural function.

\section{Conversion of agricultural land to non-agricultural}

In Bulgaria, the conversion of agricultural land for non-agricultural purposes is allowed for the construction of technical infrastructure, creating new, or expanding the existing construction areas into urban areas, and the creation or expansion of the areas intended for development, outside the developed space of the existing urban areas. When more than 50 ha of high quality and irrigated land is issued for construction, then the Council of Ministers is to give approval. Although this procedure is stipulated in the legal regulations, numerous investors obtain a building permit for land previously used for agricultural purposes. Though the administrative procedure is long and complicated, in practice, the public interest is poorly protected - we can say in a wishful manner. This process was intensified after 2006, when a number of tourism-related buildings and structures were built along the Black Sea coast and in the protected areas. This resulted in the parceling out of many small urban plots, and the areas of urban settlements were enlarged.

In Poland, the conversion to non-agricultural land is a two-stage process, which consists of the land being zoned for non-agricultural purposes at the stage of spatial planning, and the exclusion from agricultural production - an administrative procedure (KWARTNIK-PRUC et al., 2011).

For areas which are covered by the local land use plan, high suitability agricultural land (quality classes I, II, III) can be converted, but with the consent of the minister responsible for rural development.

This consent is not required for lands which meet all of the following conditions:

- at least half the surface area of each land property is contained in the area of dense frontage development,

- the land is located at a distance no greater than $50 \mathrm{~m}$ from the boundary of the nearest building plot,

- the land is located at a distance of not more than 50 meters from a public road,

- the surface does not exceed 0.5 ha, regardless of whether they form a unity or separate parts.

Exclusion of land from agricultural production is carried out for a fee - the first fee is paid, and then, for the next 10 years, annual fees are incurred. For areas covered by the local zoning plan with lower agricultural suitability (quality classes IV-VI), the conversion is the responsibility of the staroste and does not require any other arrangements. It is worth noting that according to the Protection of Agricultural and Forest Land Act (USTAWA, 1995) regarding agricultural land in the administrative boundaries of cities, there are no restrictions on the conversion of land to non-agricultural land.

\section{Real estate subdivisions}

In order to prevent excessive fragmentation of agricultural land in Poland, the subdivision of agricultural land is possible, if each parcel resulting from the subdivision has an area of at least 0.3000 ha. However, in some cases, it is allowed to parcel out smaller plots, subject to administrative procedure supervised by the municipality. This happens when (USTAWA, 1997):

- there is no local land use plan, and a planning permission (or a decision on the location of a public investment) was issued for agricultural land,

- the subdivision ensures the parceling out of plots for public roads,

- the subdivision leads to the parceling out of land with an area of less than 0.3000 hectares and it is implemented to enlarge the neighboring property or to regulate boundaries between adjacent real properties.

The Bulgarian Law (LAW, 1949) does not allow for the division of land into plots smaller than 0.3 ha for arable fields, 0.2 ha for meadows and 0.1 ha for orchards and vineyards. In actuality, however, the result of the aforementioned agrarian reform is the partial consolidation of land and the lack of regulations on the prohibition or restriction of the further subdivision of plots as a result of property inheritance and sales. The complexity of the problem is aggravated by the fact that, after the restoration of property, 1.5 million hectares of agricultural land (19.4\% of the total area of farmland) is theoretically indivisible, but the subdivision process is possible in practice. 


\section{SWOT/TOWS analysis}

In order to determine whether the methods of agricultural land protection in Poland and Bulgaria are adequate, SWOT/TOWS analysis was applied. A simplified algorithm of the analysis is as follows:

1. Describing internal and external factors which can have either a positive or negative influence on agricultural land in Poland and Bulgaria - basing off literature, legislation, the above comparative characteristics and (PAWLIKOWSKA, POPEK, 2015).

2. Assigning meaning to individual factors - by determining weights, basing on a survey conducted among students of real estate-related fields of study whose task was to rank the presented factors from most important to least important.

3. Analyzing the mutual relationships between the selected factors - ultimately, five most important factors of each category for Poland (Table 3) and Bulgaria (Table 4) were accepted for the TOWS/SWOT analysis.

The students evaluated the validity of a given factor using the five-point Tilgner scale (BABBIE, 2008), (DAWIDOWICZ, ŹRÓBEK, 2014): 1 point - lack of impact factor, 2 points - low impact factor, 3 points - average impact factor, 4 points - significant impact factor and 5 points - maximum impact factor.

Weights were determined by the transformation of the results obtained from the questionnaires using the formula:

where:

$$
W_{C}=\frac{p_{i}}{\sum p_{i}} \cdot 100 \% \text {, }
$$

i - number of factors,

$\mathrm{W}_{\mathrm{c}}$ - weight of the $i$-th factor,

$\mathrm{p}_{\mathrm{i}}$ - arithmetic mean of the $i$-th factor from a set of students' answers.

Factors of the analysis for Poland

Table 3

\begin{tabular}{|c|c|c|c|c|c|}
\hline No. & Weight & Internal factors & No. & Weight & External factors \\
\hline- & 1.00 & Strengths (S) & - & 1.00 & Opportunities (O) \\
\hline $\mathrm{S} 1$ & 0.30 & $\begin{array}{c}\text { large resources of agricultural } \\
\text { land }\end{array}$ & $\mathrm{O} 1$ & 0.30 & $\begin{array}{l}\text { international cooperation in } \\
\text { the field of agricultural } \\
\text { production }\end{array}$ \\
\hline S2 & 0.30 & $\begin{array}{l}\text { good natural conditions for } \\
\text { agriculture }\end{array}$ & $\mathrm{O} 2$ & 0.30 & $\begin{array}{c}\text { international projects to protect } \\
\text { agricultural land }\end{array}$ \\
\hline S3 & 0.20 & $\begin{array}{c}\text { preventing excessive } \\
\text { fragmentation of agricultural } \\
\text { land }\end{array}$ & $\mathrm{O} 3$ & 0.20 & $\begin{array}{c}\text { adaptation of real estate } \\
\text { information systems to EU } \\
\text { laws }\end{array}$ \\
\hline S4 & 0.10 & Agricultural Property Agency & $\mathrm{O} 4$ & 0.10 & $\begin{array}{l}\text { EU funding for agricultural } \\
\text { production }\end{array}$ \\
\hline S5 & 0.10 & $\begin{array}{l}\text { advanced systems of land } \\
\text { records }\end{array}$ & O5 & 0.10 & $\begin{array}{l}\text { letting external capital for } \\
\text { agricultural production }\end{array}$ \\
\hline- & 1.00 & Weaknesses (W) & - & 1.00 & Threats (T) \\
\hline W1 & 0.30 & $\begin{array}{l}\text { fragmented structure of } \\
\text { agricultural land }\end{array}$ & $\mathrm{T} 1$ & 0.30 & $\begin{array}{l}\text { urban development and } \\
\text { growing investments }\end{array}$ \\
\hline W2 & 0.25 & $\begin{array}{l}\text { frequent and easy changes to } \\
\text { the status of agricultural land }\end{array}$ & $\mathrm{T} 2$ & 0.20 & $\begin{array}{c}\text { decreased value of agricultural } \\
\text { land }\end{array}$ \\
\hline W3 & 0.20 & $\begin{array}{l}\text { lack of separate planning } \\
\text { procedures for farmland }\end{array}$ & $\mathrm{T} 3$ & 0.20 & closure of outlets \\
\hline W4 & 0.15 & local plans cover small area & $\mathrm{T} 4$ & 0.20 & environmental pollution \\
\hline
\end{tabular}




\begin{tabular}{llllll}
\hline W5 & 0.10 & migration to cities & T5 & 0.10 & $\begin{array}{c}\text { low financial support of the } \\
\text { State }\end{array}$ \\
\hline
\end{tabular}

Source: Own study.

Table 4

Factors of the analysis for Bulgaria

\begin{tabular}{|c|c|c|c|c|c|}
\hline No. & Weight & Internal factors & No. & Weight & External factors \\
\hline- & 1.00 & Strengths (S) & - & 1.00 & Opportunities (O) \\
\hline S1 & 0.30 & $\begin{array}{l}\text { large resources of agricultural } \\
\text { land }\end{array}$ & $\mathrm{O} 1$ & 0.30 & $\begin{array}{c}\text { international cooperation in } \\
\text { the field of agricultural } \\
\text { production }\end{array}$ \\
\hline $\mathrm{S} 2$ & 0.30 & $\begin{array}{l}\text { good natural conditions for } \\
\text { agriculture }\end{array}$ & $\mathrm{O} 2$ & 0.30 & $\begin{array}{l}\text { international projects to protect } \\
\text { agricultural land }\end{array}$ \\
\hline S3 & 0.20 & master plans cover large area & $\mathrm{O} 3$ & 0.20 & $\begin{array}{c}\text { adaptation of real estate } \\
\text { information systems to EU } \\
\text { laws }\end{array}$ \\
\hline $\mathrm{S} 4$ & 0.10 & $\begin{array}{c}\text { Land Tenure and } \\
\text { Consolidation Directorate at } \\
\text { Ministry of Agriculture and } \\
\text { Food } \\
\end{array}$ & $\mathrm{O} 4$ & 0.10 & $\begin{array}{l}\text { EU funding for agricultural } \\
\text { production }\end{array}$ \\
\hline S5 & 0.10 & $\begin{array}{c}\text { well-integrated systems of land } \\
\text { records }\end{array}$ & O5 & 0.10 & $\begin{array}{l}\text { allowing external capital for } \\
\text { agricultural production }\end{array}$ \\
\hline- & 1.00 & Weaknesses (W) & - & 1.00 & Threats $(\mathrm{T})$ \\
\hline W1 & 0.30 & $\begin{array}{l}\text { fragmented structure of } \\
\text { agricultural land }\end{array}$ & $\mathrm{T} 1$ & 0.30 & $\begin{array}{l}\text { urban development and } \\
\text { growing investments }\end{array}$ \\
\hline W2 & 0.20 & $\begin{array}{l}\text { allowable changes to the status } \\
\text { of agricultural land }\end{array}$ & $\mathrm{T} 2$ & 0.20 & $\begin{array}{c}\text { decreased value of agricultural } \\
\text { land }\end{array}$ \\
\hline W3 & 0.20 & $\begin{array}{l}\text { lack of separate planning } \\
\text { procedures for farmland }\end{array}$ & $\mathrm{T} 3$ & 0.20 & closure of outlets \\
\hline W4 & 0.20 & $\begin{array}{c}\text { there is no detailed regime for } \\
\text { the agricultural land in the } \\
\text { master plans }\end{array}$ & $\mathrm{T} 4$ & 0.20 & $\begin{array}{l}\text { poor control on the } \\
\text { environmental pollution }\end{array}$ \\
\hline W5 & 0.10 & migration to cities & T5 & 0.10 & $\begin{array}{l}\text { low financial support of the } \\
\text { State }\end{array}$ \\
\hline
\end{tabular}

Source: Own study.

It should be noted that, among the factors of the analysis, the differences between Poland and Bulgaria occur only in internal factors, and are not too great.

The mutual relationships between these factors have been illustrated in Tables 5 and 6 . If, according to the authors, a correlation exists, "1" was written in the tables. In the absence of any relationship - " 0 ".

Table 5 summarizes the answers to the following questions:

- does a strength allow given opportunity to be used?

- does a strength allow a given threat to be eliminated?

- does a weakness limit the possibility to use a given opportunity?

- does a weakness intensify the risk associated with a given threat?

Table 5

SWOT relationships for Poland and Bulgaria

\begin{tabular}{ccccccccccc}
\cline { 2 - 11 } & O1 & O2 & O3 & O4 & O5 & T1 & T2 & T3 & T4 & T5 \\
\hline S1 & $1 / 1$ & $1 / 1$ & $0 / 0$ & $1 / 1$ & $1 / 1$ & $0 / 0$ & $0 / 0$ & $0 / 0$ & $0 / 0$ & $0 / 0$ \\
\hline
\end{tabular}




\begin{tabular}{ccccccccccc}
\hline S2 & $1 / 1$ & $0 / 0$ & $0 / 0$ & $0 / 0$ & $1 / 1$ & $0 / 0$ & $0 / 0$ & $0 / 0$ & $0 / 0$ & $0 / 0$ \\
\hline S3 & $0 / 0$ & $1 / 0$ & $0 / 0$ & $1 / 0$ & $0 / 0$ & $0 / 1$ & $1 / 0$ & $0 / 0$ & $0 / 0$ & $0 / 0$ \\
\hline S4 & $1 / 1$ & $1 / 1$ & $0 / 0$ & $0 / 0$ & $0 / 0$ & $1 / 1$ & $1 / 1$ & $0 / 0$ & $0 / 0$ & $1 / 1$ \\
\hline S5 & $1 / 1$ & $1 / 1$ & $1 / 1$ & $1 / 1$ & $1 / 1$ & $0 / 0$ & $0 / 0$ & $0 / 0$ & $0 / 0$ & $0 / 0$ \\
\hline W1 & $1 / 1$ & $0 / 0$ & $0 / 0$ & $1 / 1$ & $1 / 1$ & $1 / 1$ & $1 / 1$ & $0 / 0$ & $0 / 0$ & $0 / 0$ \\
\hline W2 & $0 / 0$ & $1 / 1$ & $0 / 0$ & $1 / 1$ & $1 / 1$ & $1 / 1$ & $0 / 0$ & $0 / 0$ & $1 / 1$ & $0 / 0$ \\
\hline W3 & $0 / 0$ & $1 / 0$ & $0 / 0$ & $1 / 0$ & $1 / 0$ & $1 / 1$ & $0 / 0$ & $0 / 0$ & $0 / 0$ & $0 / 0$ \\
\hline W4 & $0 / 0$ & $1 / 0$ & $0 / 0$ & $0 / 0$ & $0 / 0$ & $1 / 1$ & $0 / 1$ & $0 / 0$ & $0 / 1$ & $0 / 0$ \\
\hline W5 & $0 / 0$ & $0 / 0$ & $0 / 0$ & $0 / 0$ & $0 / 0$ & $1 / 1$ & $1 / 1$ & $0 / 0$ & $0 / 0$ & $0 / 0$ \\
\hline
\end{tabular}

Source: Own study.

Table 6, on the other hand, summarizes the answers to the following questions:

- does an opportunity strengthen a given strength?

- does an opportunity allow a given weakness to be eliminated?

- does a threat eliminate a given strength?

- does a threat emphasize a given weakness?

Table 6

TOWS relationships for Poland and Bulgaria

\begin{tabular}{ccccccccccc} 
& S1 & S2 & S3 & S4 & S5 & W1 & W2 & W3 & W4 & W5 \\
\hline O1 & $0 / 0$ & $0 / 0$ & $0 / 0$ & $0 / 0$ & $0 / 0$ & $0 / 0$ & $0 / 0$ & $0 / 0$ & $0 / 0$ & $0 / 0$ \\
\hline O2 & $0 / 0$ & $0 / 0$ & $0 / 1$ & $0 / 0$ & $0 / 0$ & $1 / 1$ & $1 / 1$ & $1 / 1$ & $1 / 1$ & $0 / 0$ \\
\hline O3 & $0 / 0$ & $0 / 0$ & $0 / 0$ & $0 / 0$ & $1 / 1$ & $0 / 0$ & $0 / 0$ & $0 / 0$ & $0 / 0$ & $0 / 0$ \\
\hline O4 & $1 / 1$ & $0 / 0$ & $1 / 1$ & $0 / 0$ & $0 / 0$ & $1 / 1$ & $1 / 1$ & $0 / 1$ & $0 / 0$ & $1 / 1$ \\
\hline O5 & $0 / 0$ & $0 / 0$ & $0 / 0$ & $0 / 0$ & $0 / 0$ & $1 / 1$ & $1 / 1$ & $0 / 0$ & $0 / 0$ & $0 / 0$ \\
\hline T1 & $1 / 1$ & $0 / 0$ & $0 / 0$ & $1 / 1$ & $0 / 0$ & $0 / 0$ & $1 / 1$ & $0 / 1$ & $0 / 1$ & $1 / 1$ \\
\hline T2 & $0 / 0$ & $0 / 0$ & $1 / 0$ & $1 / 1$ & $0 / 0$ & $0 / 0$ & $1 / 1$ & $0 / 1$ & $0 / 1$ & $1 / 1$ \\
\hline T3 & $1 / 1$ & $0 / 0$ & $0 / 0$ & $0 / 0$ & $0 / 0$ & $1 / 1$ & $1 / 1$ & $0 / 0$ & $0 / 1$ & $1 / 1$ \\
\hline T4 & $1 / 1$ & $1 / 1$ & $0 / 0$ & $0 / 0$ & $0 / 0$ & $0 / 0$ & $1 / 1$ & $0 / 0$ & $0 / 1$ & $1 / 1$ \\
\hline T5 & $1 / 1$ & $0 / 0$ & $0 / 0$ & $0 / 0$ & $0 / 0$ & $1 / 1$ & $1 / 1$ & $0 / 0$ & $1 / 1$ & $1 / 1$ \\
\hline
\end{tabular}

Source: Own study.

Table 7 presents a complete summary of SWOT/TOWS analysis; the results of the strategic analysis and the selection of the strategy itself are contained in Table 8. The complete summary (Table 7) contains the sum of the relationships from Tables 5 and 6 , and the sum of the products of these weights and these relationships. The results of the analysis (Table 8) allow one of the strategies below to be selected (ОвŁóJ, 2001):

- aggressive strategy, if strengths prevail and there are opportunities associated with them,

- conservative strategy, if strengths prevail and there are threats associated with them,

- competitive strategy, if weaknesses prevail and there are opportunities associated with them,

- defensive strategy, if weaknesses prevail and there are threats associated with them.

Table 7

Collective results of SWOT/TOWS analysis for Poland and Bulgaria

\begin{tabular}{ccccccc} 
& \multicolumn{2}{c}{$\begin{array}{c}\text { Results of SWOT } \\
\text { analysis }\end{array}$} & \multicolumn{2}{c}{$\begin{array}{c}\text { Results of TOWS } \\
\text { analysis }\end{array}$} & \multicolumn{2}{c}{$\begin{array}{c}\text { Summary of } \\
\text { SWOT/TOWS }\end{array}$} \\
\hline Combination & $\begin{array}{c}\text { Sum of } \\
\text { interactions }\end{array}$ & $\begin{array}{c}\text { Sum of } \\
\text { products }\end{array}$ & $\begin{array}{c}\text { Sum of } \\
\text { interactions }\end{array}$ & $\begin{array}{c}\text { Sum of } \\
\text { interactions }\end{array}$ & $\begin{array}{c}\text { Sum of } \\
\text { products }\end{array}$ & $\begin{array}{c}\text { Sum of } \\
\text { interactions }\end{array}$ \\
\hline $\begin{array}{c}\text { Strengths [SV } \\
\text { Opportunities [O] }\end{array}$ & $30 / 26$ & $6.10 / 5.30$ & $6 / 8$ & $1.00 / 1.50$ & $36 / 34$ & $7.10 / 6.80$ \\
\hline $\begin{array}{c}\text { Strengths [SV } \\
\text { Threats [T] }\end{array}$ & $8 / 8$ & $1.30 / 1.40$ & $16 / 14$ & $3.60 / 3.20$ & $24 / 22$ & $4.90 / 4.60$ \\
\hline
\end{tabular}




\begin{tabular}{ccccccc}
\hline $\begin{array}{c}\text { Weaknesses [W] } \\
\text { Opportunities [O] }\end{array}$ & $20 / 12$ & $4.20 / 2.50$ & $18 / 20$ & $3.80 / 4.00$ & $38 / 32$ & $8.00 / 6.50$ \\
\hline $\begin{array}{c}\text { Weaknesses [W] } \\
\text { Threats [T] }\end{array}$ & $16 / 20$ & $1.70 / 1.70$ & $26 / 38$ & $4.90 / 7.30$ & $42 / 58$ & $6.60 / 9.00$ \\
\hline
\end{tabular}

Source: Own study.

Table 8

Results of the strategic analysis and strategy selection for Poland and Bulgaria

\begin{tabular}{ccc}
\cline { 2 - 3 } & \multicolumn{1}{c}{ Opportunities } & \multicolumn{1}{c}{ Threats } \\
\cline { 2 - 3 } Strengths & Aggressive strategy & Conservative strategy \\
\cline { 2 - 3 } & Number of interactions & Number of interactions \\
\cline { 2 - 3 } & $36 / 34$ & $24 / 22$ \\
\cline { 2 - 3 } & Weighted number of interactions & Weighted number of interactions \\
\cline { 2 - 3 } Weaknesses & $7.11 / 6.80$ & $4.90 / 4.60$ \\
\cline { 2 - 3 } & Competitive strategy & Defensive strategy \\
\cline { 2 - 3 } & Number of interactions & Number of interactions \\
\cline { 2 - 3 } & $38 / 32$ & Weighted number of interactions \\
\cline { 2 - 3 } & Weighted number of interactions & $6.60 / 9.00$ \\
\hline
\end{tabular}

Source: Own study.

Unfortunately, the performed analyses do not provide a clear answer as to the correctness of the methods of agricultural land protection in Poland. The number of interactions and the weighted number of interactions are very similar in the case of as many as three strategies. This means that Poland should care about the strengths related to its agricultural land resources and use the opportunities for their further development, while trying to eliminate its weaknesses (Table 3). According to the authors, it is advisable to try to make some changes in the Spatial Planning and Development Act (Act, 2003a), which would result in the need to create obligatory separate planning documents for the protection of agricultural land. Such documents could also impede the conversion of agricultural land for non-agriculturaluses, which is currently being implemented by means of local land use plans, created primarily for investment purposes. Additionally, to prevent the fragmentation of the structure of agricultural land, the procedure of land consolidation and exchange should become more common.

The analysis performed for Bulgaria, however, suggests that the resources of agricultural properties in this country are at the survival stage, because weaknesses and associated threats prevail (Table 4). This means that the country should quickly take steps to improve the state of agricultural real property resources. Prevention of the possibilities of developing agricultural land seems to be the most urgent. The lack of any restrictions on the enlargement of land for construction projects may cause an uncontrolled decrease in the area of good quality agricultural land.

\section{Summary}

Proper protection of land with high suitability for agricultural production and, at the same time, its compliance with the principles of sustainable development, is a matter of great importance. The presented analysis allowed to identify the problems and to make recommendations for the proper management of agricultural land which ought to be considered in the new EU countries. First of all, there should exist more imperative and restrictive legal measures for preventing the transition of agricultural land into non-agricultural; secondly, agricultural territory with all of its functional linear and area elements and regime for land use should be considered in spatial planning; thirdly, environmental protection in agricultural territory and in the surrounding environment should be more imperatively guaranteed by legal and normative documents; fourth, the cadastral maps and registers should be maintained for the entire territory of the country to ensure better protection of ownership and property rights. Apart from the above, Bulgaria needs sound legislation against 
further fragmentation by market sales, inheritances and other forms of land relationships. A strategy for land development, including agricultural land development, and effective land policy are the key drivers of proper and advantageous land management.

The general profile of the countries presented in the article exhibits some differences in the natural conditions. However, as far as the size of agricultural land resources relative to the percentage of the total land area is concerned, they are comparable both in Poland and in Bulgaria. This refers to areas which are actually used for agricultural purposes, as well as to land which is potentially suitable for agricultural purposes.

Both, in Poland and in Bulgaria, public records relating to the real estate are two separate, but closely-related datasets. The stage of their development is rather comparable, although the Bulgarian cadastre seems to be at a slightly higher level of integration with other public registers. On the other hand, the scope of the cadastral data in Poland is more extensive and serves as a basis for land management and planning in a better way.

Spatial planning in both countries has an influence on the protection of agricultural land, but to a limited extent. Agricultural areas are only identified in the planning documents. There are no rules which would affect the development and shaping of the areas intended for agricultural purposes or the development of infrastructure in this area. According to the authors, additional legal provisions should be created, which would complement the spatial planning system in Poland and Bulgaria, because, only thanks to legislation supporting the development of the agricultural land, can spatial planning become a tool for rational agricultural production.

Although the conversion of agricultural land to non-agricultural land in Poland is associated with a number of procedures and fees, which are relatively high, the scale of changes to its status is quite large. The regulations aimed at limiting the conversion of land for non-agricultural purposes and preventing negative impacts on agricultural land tend to be vague and, consequently, the agricultural area is systematically decreasing. The total agricultural area in Bulgaria is decreasing as well. The Agricultural Land Protection Act has introduced very liberal procedures for changes to the original use of agricultural land. This demonstrates that the investment pressure on agricultural land is evident in both countries. Moreover, the lack of full protection of agricultural land results in speculative land purchase, and consequently, this makes agricultural land unavailable for individuals engaged in agricultural production. There is a need to create appropriate instruments for the protection of agricultural land in this respect.

As far as restrictions on the development of farmland are concerned, some shortcomings were noticed as well. In Bulgaria, a major failure is that part of an agricultural real property can be developed with a residential building, which could lead to improper management of the land suitable for agriculture. In Poland, due to the lack of local land use plans, this issue is regulated through a planning permission. This permission is regarded as a defective planning instrument due to its individual character and no connection with the general planning policy. In addition, preventive measures, such as fees for changing the status of agricultural land, fail to fulfill their function.

\section{References}

BABBIE E., 2008., Fundamentals of Social Research (in Polish), PWN, Warszawa.

BRABEC E., SMith C., 2002, Agricultural land fragmentation: the spatial effects of three land protection strategies in the eastern United States, Landscape and Urban Planning, vol. 58 no 2, pp. 255-268.

BIEDA A., JASIŃSKA E., PREWEDA E., 2014, Surveying protection of agricultural land in Poland, International Conference on Environmental Engineering, Vilnius, Lithuania.

CADASTER and Property Register Act (CPRA), Official Gazette of RBulgaria, 34/2000, with further amendments.

Davidova S., BuCKWEll A., Kopeva D., SWInNEN J. F. M., MATHIJS E., 1997, Bulgaria: economics and politics of post-reform farm structures, Agricultural privatization, land reform and farm restructuring in Central and Eastern Europe, pp. 23-62.

DAWIDOWICZ A., ŹROBEK R., 2014, Multipurpose water-marine cadastre in Poland-development directions, Acta Adriatica, vol. 55(2), pp. 127-144.

FELCENLOBEN D., 2010, Zadania i funkcje katastru nieruchomości (Tasks and functions of the real estate cadastre), Świat Nieruchomości, nr 3 (73), pp. 20-23. 
GŁÓWNy URZĄD STATYSTYCZNY (GUS), 2014, Rocznik statystyczny rolnictwa (Statistical Yearbook of Agriculture), Warszawa.

KAZANDJIEV V., GEORGIEVA V., MoteVA M., 2009, Climate change, agroclimatic resources and agroclimatic zoning of agriculture in Bulgaria, 9-th EMS. In ECAM Conference, Toulouse, France.

KWARTNIK-PRUC A., BYDŁOSZ J., PARZYCH P., 2011, Analiza procesu przeznaczenia gruntów rolnych I leśnych na cele inwestycyjne (The analysis of the process of destining agricultural and forest land for investment purposes), Studia i Materiały Towarzystwa Naukowego Nieruchomości, vol. 19 no 4, pp. 169-179.

LAW on Succession, Official Gazette of RBulgaria, 22/29.01.1949 with further amendments.

LAW on Ownership and Use of the Agricultural Lands, Official Gazette of RBulgaria, 17/1991 with further amendments.

LAW on Protection of Agricultural Land, Official Gazette of RBulgaria, 35/1996 with further amendments.

LAW on Stock Companies with Special Investment Objective, Official Gazette of RBulgaria, 46/2003 with further amendments.

MINISTRY of Agriculture and Food in Republic of Bulgaria (MAF), http://www.mzh.government.bg/mzh/ en/Home.aspx, access: 15.02.2016.

Moteva M., MOndeShKA M., StOeVA A., YARLOVSKA N., 2014, Contemporary issues of land use and water management for agriculture in Bulgaria, Lucrări ştiințifice, vol. 57 no 2, pp. 59-68.

OвŁój K., 2001, Strategia organizacji (Organization strategy), PWE, Warszawa.

PRUS B., SALATA T., 2014, Influence of physiographic conditions on the quality of agricultural production area, Geomatics and Environmental Engineering, vol. 8 no 4, pp. 55-65.

PAWLIKOWSKA E., POPEK P., 2015, Management of agricultural land resources in Poland and Bulgaria - the comparative study, master thesis, unpublished.

RĄCKA I., PALICKI S., KOSTOV I., 2015, State and Determinants of Real Estate Market Development in Central and Eastern European Countries on the Example of Poland and Bulgaria, Real Estate Management and Valuation, vol. 23 no 2, pp. 77-90.

REGIONAL Development Act - RDA, Official Gazette of RBulgaria, 50/2008 with further amendments.

REGULATION of the Law on Ownership and Use of Agricultural Lands, Official Gazette of RBulgaria, 34/1991, with further amendments.

ROZPORZĄDZENIE Ministra Rozwoju Regionalnego i Budownictwa z dnia 29 marca 2001 r. w sprawie ewidencji gruntów i budynków, tj. z dnia 10 czerwca 2016 r., Dz. U. z 2016 r., poz. 1034, z pózn. zm. [Regulation of the Minister of Regional Development and Construction of 29 March 2001 on the registration of land and buildings, consolidated text of 10 June 2015, Journal of Laws of 2016, item 1034, as amended].

SKINNER M. W., KuHN R. G., JOSEPH A. E., 2001, Agricultural land protection in China: a case study of local governance in Zhejiang Province, Land Use Policy, vol. 18 no 4, pp. 329-340.

SPATIAL Planning Act - SPA, Official Gazette of RBulgaria, 1/2001 with further amendments.

THE WORLD FACTBOOK, https://www.cia.gov/library/publications/the-world-factbook, access: 15.02.2016.

USTAWA z 23 kwietnia 1964 r. - Kodeks cywilny, tj. z dnia 17 grudnia 2013 r., Dz. U. z 2014 r. poz. 121, z pózn. zm. [Act of 24 April 1964 - Civil Code, consolidated text of 17 December 2013, Journal of Laws of 2014, item 121, as amended].

USTAWA z dnia 26 marca 1982 r. o scalaniu i wymianie gruntów, tj. z dnia 12 marca 2014 r., Dz. U. z 2014 r., poz. 700, z późn. zm., 1982a [Act of 26 March 1982 on Land Consolidation and Exchange, consolidated text of 12 March 2014, Journal of Laws of 2014, item 700, as amended].

USTAWA z dnia 6 lipca 1982 r. o ksiegach wieczystych i hipotece, tj. z dnia 5 kwietnia 2013 r., Dz. U. z 2013 r., poz. 707, z późn. zm., 1982b [Act of 6 July 1982 on Land and Mortgage Registers and on Mortgage, consolidated text of 5 April 2013, Journal of Laws of 2013, item 707, as amended].

UstAWA z 17 maja 1989 r. - Prawo geodezyjne i kartograficzne, tj. z dnia 18 marca 2015 r., Dz. U. z 2015 r., poz. 520, z pózn. zm. [Act of 17 May 1989 - Surveying and Mapping Law, consolidated text of 18 March 2015, Journal of Laws of 2015, item 520, as amended].

UsTAWA z dnia 3 lutego 1995 r. o ochronie gruntów rolnych i leśnych, tj. z dnia 9 czerwca 2015 r., Dz. U. z 2015 r., poz. 909, z pózn. zm. [Act of 3 February 1995 on the Protection of Agricultural and Forests Land, consolidated text of 9 June 2015, Journal of Laws of 2015, item 909, as amended]. 
USTAWA z 21 sierpnia 1997 r. o gospodarce nieruchomościami, tj. z dnia 30 października 2015 r., Dz. U. z 2015 r. poz. 1774, z pózn. zm. [Act of 21 August 1997 - about real estate management, consolidated text of 30 October 2015, Journal of Laws of 2015, item 1774, as amended].

UstAWA z dnia 27 kwietnia 2001 r. - prawo ochrony środowiska, tj. z dnia 26 sierpnia 2013 r., Dz. U. z 2013 r., poz. 1232, z pózn. zm., [Act of 27 April 2001 - Environmental Protection Law, consolidated text of 26 August 2013, Journal of Laws of 2013, item 1232, as amended].

UstAWA z dnia 27 marca 2003 r. o planowaniu $i$ zagospodarowaniu przestrzennym, tj. z dnia 5 lutego 2015 r., Dz. U. z 2015 r., poz. 199, z pózn. zm., 2003a [Act of 27 March 2003 - about spatial planning and development, consolidated text of 5 Februar 2015, Journal of Laws of 2015, item 199, as amended].

USTAWA z dnia 11 kwietnia 2003 r. o kształtowaniu ustroju rolnego, tj. z dnia 28 czerwca 2012 r., Dz. U. z 2012 r., poz. 803, z pózn. zm., 2003b [Act of 11 April 2003 on Shaping of the Agricultural System, consolidated text of 28 July 2012, Journal of Laws of 2012, item 803, as amended].

UsTAWA z dnia 14 kwietnia 2016 r. o wstrzymaniu sprzedaży nieruchomości zasobu własności rolnej skarbu państwa oraz o zmianie niektórych ustaw, Dz. U. z 2016 r. poz. 585 [Act of 14 April 2016 on suspension of sale of property from the Agricultural Property Stock of the State Treasury and amendment to certain acts, Journal of Laws of 2016, item 585]. 